\title{
Workout sebagai gaya hidup sehat wanita modern
}

\author{
Rossa Fitriana ${ }^{\mathrm{a}, 1}$, Diaz Restu Darmawan ${ }^{\mathrm{b}, 2^{*}}$ \\ ab Universitas Tanjungpura, Jalan Prof. Dr. H. Hadari Nawawi, Pontianak, 78142, Indonesia \\ ${ }^{1}$ rossafitriana@student.untan.ac.id ; ${ }^{2}$ diaz.rd@fisip.untan.ac.id
}

Corresponding Author

\begin{tabular}{l}
\hline INFO ARTIKEL \\
\hline Sejarah Artikel: \\
Diterima: 29 Juli 2021 \\
Direvisi: 6 September 2021 \\
Disetujui: 21 September 2021 \\
Tersedia Daring: 31 Oktober \\
2021 \\
\hline
\end{tabular}

\section{ABSTRAK}

Penelitian ini membahas mengenai fenomena gaya hidup yang baru muncul pada wanita modern di perkotaan. Gaya hidup yang muncul ini adalah usaha untuk meningkatkan kualitas tubuh yang sehat dengan aktivitas workout. Faktor kehidupan masyarakat modern, khususnya wanita modern di perkotaan yang sudah sangat tergantung pada

Kata Kunci:

Budaya

Gaya Hidup

Modernitas wa membuat perilaku kesehatan workout semakin melekat dalam kehidupan modernitas. Hal ini menunjukkan peran media sosial tidak sebatas sebagai komunikasi

Perilaku Kesehatan melainkan juga sebagai media kesehatan. Penelitian ini dilakukan dengan metode kualitatif dalam menganalisis bagaimana kemunculan gaya hidup workout terutama pada kalangan wanita perkotaan. Dalam pengumpulan data digunakan metode etnografi dengan mewawancarai informan melalui jaringan media sosial. Melalui teori self efficacy, tulisan ini menjelaskan aktivitas workout merupakan hasil meniru dari postingan-postingan media sosial. Dalam poses peniruannya mempertimbangkan aspek compliance, identification, dan internalization. Tulisan ini memunculkan narasi gaya hidup workout sebagai konsep kesehatan baru di kehidupan manusia yang telah terdigitalkan. Terjadi perubahan konsep sehat yang tidak sebatas terhindar penyakit dari tubuh, tetapi dapat sebagai bentuk pemenuhan gaya hidup yang menjadi prioritas masyarakat modern. Ditambah faktor pandemi, kegiatan workout menjadi pilihan utama untuk meningkatkan kualitas kesehatan disaat kebijakan untuk mengurangi kegiatan di luar rumah.

\section{ABSTRACT}

Keywords:

Cultural

Lifestyle

Modernity

Health Behavior
This research will discuss the new lifestyle phenomenon that has just emerged in the urban area around the modern women, the lifestyle itself emerged from the notion in attempt to improve the quality of the healthy body with workout activities, The factor of living in modern society, especially around the modern women in urban areas who are already highly dependent on social media and various mobile applications, make a healthy behavior such as "workout" increasingly embedded in modern life. This suggests that the role of social media is not limited to just media for communication but also health media. This research will be conducted in the qualitative method in analyzing how the emergence of the so-called workout lifestyle happened, more specifically around urban women. The ethnography method will be used in the process of collecting the data with the interview of the informant through social media networks. Through self-efficacy theory, this research will explain how the activity such as workout is an output of a replicate from the social media posts. The process of replicating will be based on aspects such as compliance, identification, and internalization. This article will show the narration of the workout lifestyle as a new health concept in human life that has been digitalized. There's a change in health concept that's not limited avoid disease from the body, but also could be a form of fulfilling the lifestyle that has become a priority in modern society. The factor of pandemic also makes the workout activities become the primary choice to improving the quality of health when the policy is to reduce activities outside the home. 


\section{Pendahuluan}

Pada kehidupan masyarakat modern saat ini banyak ditemui perilaku-perilaku yang mendasari sebuah gaya hidup seseorang. Gaya hidup yang muncul pada setiap orang dipengaruhi oleh faktor lingkungan. Fenomena kehidupan dalam masyarakat modern umumnya dipengaruhi oleh faktor perkembangan yang ada di lingkungan sekitarnya. Gaya hidup dapat dilakukan oleh seluruh kalangan manusia, apapun usianya maupun jenis kelaminnya. Di era modern ini, gaya hidup diartikan sebagai suatu hal yang dapat menggambarkan tindakan dalam hidup seseorang maupun orang lain.

Pembahasan mengenai fenomena gaya hidup masyarakat modern pastinya telah memiliki banyak referensi. Seperti gaya hidup hedonisme masyarakat Desa Tateli (Doloy et al., 2020). Penelitian tersebut menginformasikan bahwa aspek yang mendasari gaya hidup seseorang adalah karena seseorang itu ingin terlihat dominan dalam suatu kelompok masyarakat. Akibatnya, masyarakat modern cenderung untuk mencari sesuatu yang sedang menjadi trend saat ini. Hal tersebut akhirnya menimbulkan sifat konsumerisme yang sangat tinggi karena setiap orang ingin menjadi dominan di dalam kelompoknya.

Selain itu terdapat pembahasan yang melihat gaya hidup yang bersifat konsumtif (Martha et al., 2020). Gaya hidup seseorang dapat disebabkan oleh kelompok pertemanan. Gaya hidup yang sedang dilakukannya semata-mata untuk mendapatkan pengakuan di dalam kelompok pertemanannya. Ia juga menyatakan gaya hidup konsumtif disebabkan oleh beberapa faktor, yakni iklan atau promotor. Maksudnya, banyak publik figur yang menjadi model iklan sebuah produk, serta status sosial yang juga menjadi pemicu gaya hidup konsumtif.

Meskipun begitu, tetapi tidak semua gaya hidup diidentifikasi sebagai perilaku yang tidak menyehatkan semata. Salah satunya terjawab pada artikel yang melihat fenomena trending-nya gaya hidup bersepeda (Utomo, 2020). Bersepeda bagian dari olahraga yang sedang digandrungi oleh masyarakat perkotaan. Selain menjadi alat transportasi, sepeda juga menjadi gaya hidup sehat baru yang diadopsi masyarakat untuk menjaga kebugaran jasmani. Kemudahan dan kenyamanan dalam bersepeda menjadikan olahraga itu banyak diminati oleh masyarakat di berbagai kalangan.

Selanjutnya sebuah tulisan lain yang membahas mengenai gaya hidup sehat melalui aktivitas gym (Rohman, 2020). Dinyatakan bahwa fitness merupakan gaya hidup yang tidak hanya bertujuan untuk mendapatkan tubuh yang ideal, melainkan juga menjadi representasi status sosial melalui berbagai simbol dan sarana memanfaatkan waktu luang.

Dari banyaknya tulisan sebelumnya yang mengkaji fenomena gaya hidup, ada isu yang menarik untuk difokuskan adalah kesehatan. Kesehatan sangat penting bagi kehidupan manusia agar selalu dapat menjalankan aktivitas dengan lancar. Secara umum, kesehatan diartikan sebagai suatu kondisi fisik, mental, dan sosial yang berjalan dengan baik dan tidak memiliki gangguan. Untuk selalu dalam keadaan yang sehat, masyarakat selalu berusaha mencapai kualitas kesehatan yang baik dengan cara melakukan gaya hidup sehat. Beragam bentuk perilaku sehat dapat menjadi trend suatu gaya hidup. Gaya hidup sehat tidak hanya sebatas olahraga, tetapi dapat dalam 
bentuk kegiatan lain yang menjunjung aspek-aspek kesehatan. Misalnya, dapat berupa konsumsi makanan yang bernutrisi, membersihkan lingkungan sekitar, hingga menjaga kualitas kesehatan fisik dan psikis (Susanti \& Kholisoh, 2018). Segala tindakan manusia yang berpotensi meningkatkan kualitas hidup dapat masuk ke dalam kategori pola gaya hidup sehat.

Bagi beberapa kelompok masyarakat tujuan hidup sehat selain untuk mendapatkan kondisi sehat pada tubuh yang bagus juga untuk dilihat dan bisa mempengaruhi orang lain untuk mengikuti pola sehat mereka (Susanti \& Kholisoh, 2018). Sehat merujuk pada suatu perasaan mental yang tercerminkan dari pikiran yang sehat dan emosional sehat. Di sisi lain, kesehatan spiritual tercermin pada cara seseorang bersyukur, memuji, dan percaya terhadap Tuhannya.

Sakit diartikan pada suatu kondisi fisik, emosi, intelektual, sosial, dan perkembangan seseorang terganggu atau tidak normal. Menurut Perkins (1939) (dalam Primanita, 2011), sakit adalah kondisi ketika seseorang merasa tidak nyaman sehingga dapat menyebabkan terganggunya aktivitas sehari-hari. Menurut Parsons (dalam Triyono \& Herdiyanto, 2018), sakit merupakan gangguan pada seluruh kondisi tubuh seseorang, meliputi adanya gangguan biologis dalam tubuh dan gangguan pada kehidupan sosialnya. Sakit dapat disebabkan oleh beberapa hal, seperti gaya hidup yang tidak sehat, lingkungan tempat tinggal yang kotor, maupun karena metabolisme tubuh yang menurun. Pemahaman dari pemaknaan konsep sehat dan sakit mempengaruhi perilaku-perilaku manusia. Mulai dari apa yang ia makan, minum maupun konsumsi dipengaruhi bagaimana rasa sehat dan rasa sakit tergantung pada masing-masing konsep. Selain itu juga pemahaman sehat dan sakit dapat pula berdampak kepada kepribadian dan nilai-nilai karakter. Perilaku sehat yang diterapkan dapat mempengaruhi karakter pelakunya (Suharjana, 2019). Hal ini karena terdapat pengendalian diri bagi manusia yang menjalankan aktivitas demi mengejar standar kesehatan yang dikehendaki, seperti mensyukuri yang telah didapatkan dari apa yang telah dilakukan.

Sejak memasuki tahun 2020 perilaku manusia bisa dikatakan hampir mengalami banyak perubahan besar. Banyak perubahan-perubahan perilaku yang harus dilakukan di rumah karena situasi pandemi Covid-19. Fenomena di Indonesia sangat beragam, mulai dari muncul kembali gaya hidup tradisional, seperti tolak bala pada masyarakat Dayak tradisional (Loischofeer \& Darmawan, 2021) hingga gaya hidup modernitas. Gaya hidup tersebut membutuhkan tingkat kualitas kesehatan yang baik tetapi sekaligus memenuhi kebutuhan gaya hidup modern pada kehidupan modern.

Bila melepaskan konsep sehat, maka gaya hidup dapat menjadi suatu gambaran perilaku yang dijalani seseorang di dalam sebuah masyarakat. Di sini gaya hidup dinilai sebagai kebiasaan manusia yang dilakukan secara berulang-ulang dan menjadi budaya dalam kelompok tertentu. Kebiasaan gaya hidup tertentu tersebut juga menentukan kualitas kesehatan dan kehidupan para pelakunya. Bila seseorang telah terbiasa melakukan kebiasaan yang bersifat sehat dan positif, maka kualitas hidup yang mereka miliki juga akan meningkat (Choirudin, 2015). Berlaku juga sebaliknya, bila kebiasaan yang dilakukan negatif maka kualitas hidup juga akan menurun. Terkadang standar positif maupun negatif suatu kebiasaan tergantung pada kebudayaan masing-masing kelompoknya.

Bila seseorang menjalani gaya hidup sehat, maka ia akan selalu memperhatikan hal-hal yang dapat mempengaruhi kesehatan, seperti pola makan, nutrisi makanan, emosi, lingkungan yang sehat, dan kemauan berolahraga sehingga ia akan mendapatkan tingkat kesehatan yang baik pula. Dengan demikian kualitas hidup orang tersebut akan meningkat. Sebaliknya, bila gaya hidup seseorang mengarah pada tindakan yang merusak kesehatan mulai dari memakan makanan instan, jarang 
berolahraga, perokok aktif, tidak dapat mengendalikan stress, dan kualitas lingkungan yang kotor akan bardampak buruk pada kondisi kesehatan seseorang. Seseorang dengan gaya hidup tidak sehat sangat mudah terkena penyakit dan menjadikan kualitas hidup seseorang menjadi menurun (Khairunnisa et al., 2015). Dalam beberapa waktu terakhir terdapat perubahan yang secara perlahan meninggalkan gaya hidup yang serba instan tersebut. Fakta kuatnya pengaruh dunia digital dan kesadaran yang cukup tinggi memunculkan gaya hidup baru yang sifatnya berlawanan dengan hasil sebelumnya.

Ilmu pengetahuan dan teknologi yang semakin canggih memberikan pengaruh terhadap gaya hidup masyarakat. Wabah modernisasi dan globalisasi cepat sekali menyatu dalam kehidupan masyarakat saat ini (Safuwan, 2007). Melalui internet dan media sosial masyarakat dengan mudah menyadari betapa pentingnya menjaga kesehatan. Hal ini terjadi karena media sosial memberikan kebutuhan secara kognitif, afektif, integrasi personal, integrasi sosial dalam media hiburan (Prihatiningsih, 2017). Di media sosial banyak dijumpai kampanye ajakan pola hidup sehat, seperti ajakan memakan makanan bernutrisi seimbang, olahraga teratur, kebiasaan tidur yang baik, tidak mengkonsumsi makanan instan, dan lain-lain. Ajakan itu datang dari fakta bahwa di zaman yang semakin modern masyarakat cenderung memiliki kebiasaan perilaku yang tidak sehat, seperti sering mengkonsumsi junk food dan kurang berolahraga.

Fenomena tersebut menjelaskan dari hasil penelitian mengenai perubahan gaya hidup masyarakat juga telah diteliti sebelumnya (Misbahuddin \& Sholihah, 2018). Pada tulisan tersebut dinyatakan bahwa masyarakat selalu memiliki selera dan minat yang berubah-ubah seiring dengan berkembangnya zaman. Dalam penelitian tersebut diungkapkan bahwa nilai-nilai budaya berpakaian masyarakat Yogyakarta telah mengalami perubahan ke arah modernisasi karena dipengaruhi oleh trend fashion Barat.

Fenomena tersebut menunjukkan bahwa tujuan yang ingin dicapai oleh seseorang tidak terlepas dari perasaan untuk membangun kepercayaan diri. Hal ini terjadi karena di lingkungan sosial masyarakat saat ini citra seseorang dinilai dari gaya hidup yang dilakukannya (Susanti \& Kholisoh, 2018). Masyarakat dapat menilai apakah orang tersebut peduli terhadap penampilannya dan mampu menilai kepribadian seseorang dari gaya hidupnya. Masyarakat telah menetapkan standar pada hidup seseorang, termasuk pula dalam hal kesehatan. Bahkan standar kecantikan juga dapat ditentukan melalui media sosial dan menjadi realitas yang natural (Hermawati et al., 2016). Orang yang menjalani gaya hidup sehat dinilai pasti memiliki tubuh yang ideal. Maka dari itu untuk memenuhi standar di mata masyarakat seseorang berusaha untuk memperbaiki gaya hidupnya menuju lebih sehat, seperti dengan beraktivitas workout.

Dari latar belakang di atas peneliti tertarik untuk melakukan penelitian ini, dengan tujuan untuk mendeskripsikan fenomena pola perilaku melalui teori self efficacy yang ditunjukkan oleh pelaku kegiatan workout dan apa pertimbangan yang mendasari aktivitas workout dilakukan, khususnya para wanita modern. Wanita modern yang dimaksud adalah wanita yang aktif mengonsumsi informasi dari media sosial, khusunya Instagram. Isu workout dalam gaya hidup masih terbilang sangat baru. Belum terdapat pembahasan bagaimana teknologi digital memberikan dampak kesehatan melalui gaya hidup yang trending. Workout lebih banyak digemari di kalangan wanita yang sudah lekat dengan dunia media sosial. Hal ini patut disayangkan karena akan memunculkan diskursus pembahasan yang menarik, utamanya bagaimana para wanita modern ini mampu menjaga kesehatan mereka dengan bantuan teknologi internet.

Melalui tulisan ini peneliti membawa pemikiran bahwa tidak semua dampak dari dunia internet selalu bersifat negatif. 
Perilaku konsumtif sudah melekat dan telah menjadi identitas dari setiap manusia modern. Sudah saatnya kita harus menerima perubahan-perubahan perilaku manusia yang serba instan dan cepat. Selain itu, melalui pembahasan ini, diperoleh pemahaman bagaimana dunia digital ikut mempengaruhi kualitas kesehatan masyarakat, walau harus terbungkus dalam gaya hidup yang harus melalui proses konsumtif dan kapitalis.

\section{Metode}

Tulisan ini berdasarkan hasil penelitian kualitatif yang bertujuan untuk mendeskripsikan hasil penelitian berupa tulisan kata-kata atau kalimat (Afrizal, 2017). Peneliti berusaha untuk menggambarkan relitas sosial yang terjadi berdasarkan data dari perbuatan manusia yang dikumpulkan. Jenis penelitian ini menggunakan pendekatan fenomenologi, di mana peneliti berusaha untuk menjelaskan atau mengungkapkan sebuah fenomena pengalaman yang terjadi pada individu dengan penuh kesadaran. Dalam hal ini, peneliti berusaha untuk menjelaskan pengalaman individu yang telah melakukan aktivitas workout.

Dalam mengkaji fenomena ini, peneliti menggunakan pendekatan etnografi virtual atau netnografi. Netnografi merupakan penelitian terbaru yang mengeksplorasi atau mengkaji bentuk komunikasi dan perilaku pengguna internet (Achmad \& Ida, 2018). Menurut Hine (2000), etnografi virtual adalah etnografi yang dilakukan di dunia maya dengan tujuan untuk memberikan pemahaman yang khas dari signifikasi dan implikasi dari para pengguna internet. Dalam pengumpulan data penulis aktif di dunia maya untuk melihat secara rinci setiap akun Instagram para pelaku workout. Metode ini cocok digunakan untuk mengkaji fenomena sosial yang terjadi di dunia internet yang sangat luas.

Penelitian etnografi virtual dapat digunakan untuk mengidentifikasi bentuk perilaku, kehidupan hingga relasi sosial secara virtual di dunia internet. Metode tersebut sangat efektif karena di dunia modern saat ini media sosial memberikan efek yang kuat terhadap gaya hidup manusia, khusunya pada remaja (Tewal et al., 2018). Melalui observasi secara virtual, peneliti berusaha untuk menggali dan memahami aktivitas workout yang sering diakses melalui media video online, seperti youtube.

Sumber data yang digunakan dalam penelitian terdiri dari data primer dan data sekunder (Zed, 2014). Sumber data primer berasal hasil wawancara terhadap tiga orang wanita yang aktif melakukan workout dan rutin memposting kegiatannya melalui media sosial. Wawancara dilakukan melalui media komunikasi digital yakni WhatsApp dan melalui observasi pada tiga akun sosial media penggiat atau promotor workout. Sumber data sekunder didapatkan melalui hasil review dari literatur yang memberikan data bagi penyusunan tulisan ini.

Banyaknya informasi data yang didapatkan dari beragam media sosial, diperlukan proses reduksi data sebelum dianalisis (Bungin, 2017). Proses reduksi data terfokuskan pada informasi bagaimana para wanita melalukan kegiatan workout dan faktor apa saja yang memutuskan mereka untuk melakukannya. Dari hasil reduksi data tersebut maka penyajian data dapat disederhanakan dan membantu proses analisis dan validasi. Melalui hal tersebut diperoleh data akhir yang dapat disajikan dan ditarik suatu kesimpulan yang sistematis.

\section{Hasil dan Pembahasan}

\subsection{Fenomena Gaya Hidup Workout}

Masyarakat modern yang tinggal di perkotaan diindentikkan dengan gaya hidup yang kurang sehat, karena dianggap lebih menyukai makanan cepat saji, malas berolahraga, kurang istirahat, merokok, minum minuman keras. Gaya hidup ini akan menurunkan kualitas kesehatan tubuh. Walaupun demikian, banyak pula ditemukan masyarakat yang menjalani pola hidup sehat. Fenomena di mana masyarakat perkotaan yang beralih memakan sayuran organik menjadi salah satu indikator yang 
dapat dilihat bahwa masyarakat modern juga mulai menjalankan gaya hidup sehat. Begitupula halnya dengan olahraga, banyak tempat-tempat latihan olahraga yang mudah ditemui di kota. Jika tidak sempat, smartphone pun bisa digunakan untuk mengakses workout.

Workout telah menjadi trend pada kalangan modern, khususnya di perkotaan. Hal itu tak terlepas dari pengaruh perkembangan internet yang semakin maju. Masyarakat dapat dengan mudah mengakses beragam aktivitas workout. Seperti yang telah dijelaskan sebelumnya bahwa workout memiliki banyak jenis. Seperti yang dilansir dari berita daring (Winastya, 2020) jenis-jenis workout yang sedang digandrungi saat ini yaitu (1) 7minute workout, yakni olahraga yang dilakukan secara singkat atau hanya dalam waktu 7 menit. Dalam 7-minute workout terdapat 12 macam gerakan latihan fisik yang dilakukan dengan masing-masing waktu 30 detik pada setiap gerakannya; (2) zumba adalah olahraga yang mirip dengan aerobik yang memadukan gerakan berbagai tarian dan selalu diiringi musik; (3) yoga yakni olahraga yang sangat populer biasanya dilakukan untuk meningkatkan kualitas fisik dan mental seseorang, seperti relaksasi dan meditasi; (4) pilates adalah olahraga yang berfokus pada teknik pernapasan dan latihan keseimbangan postur tubuh; (5) bodycombat adalah jenis olahraga yang tergolong berat dimana dalam gerakannya menggabungkan beberapa seni bela diri; (6) crossfit adalah jenis olahraga yang menggabungkan gerakan aerobik, fitness, dan yoga; (7) pound yakni olahraga yang menggunakan alat khusus berupa stik drum.

Gaya hidup yang muncul mengikuti trend yang populer di masa tersebut. Sama halnya yang dijelaskan pada tulisan yang membahas gaya hidup hedon yang memunculkan perilaku konsumtif (Lodeng, 2018). Dijelaskan bila perilaku kesehatan diawali dari perilaku yang mencoba untuk meniru perilaku orang lain dan kemudian dilakukan banyak orang. Setiap orang akan memengaruhi melalui media sosial dan akhirnya menjadi sebuah gaya trending di masanya.

Melalui media sosial, seseorang dapat melihat, menilai, dan meniru gaya hidup orang lain. Dari media sosial pula, seseorang secara tidak langsung dapat mengajak orang lain untuk bergaya hidup sehat. Maka dari itu, media sosial berfungsi sebagai kegiatan yang mengkampanyekan dan mengajak orang lain untuk memiliki gaya hidup sehat melalui workout.

Keberhasilan seseorang dalam menjalankan aktivitas workout juga menjadikan faktor orang lain untuk mengikuti pola gaya hidup yang sama. Adanya dorongan seseorang untuk berperilaku karena mempercayai yang dilakukan oleh orang lain dan menunjukkan hasil yang memuaskan (Martha et al., 2020). Karena keberhasilan seseorang tersebut bisa jadi merupakan tujuan yang ingin dicapai orang lain. Semisal seperti seseorang yang melalukan workout sukses menurunkan berat badan, maka orang lain yang memiliki keinginan untuk menurunkan berat badan pun mengikuti aktivitas workout yang dilakukan orang yang telah berhasil. Dari hal inilah akhirnya yang menjadikan workout sebagai trend gaya hidup sehat yang sedang banyak diminati oleh generasi modern saat ini. Dengan melakukan beragam aktivitas workout yang mudah didapatkan, seseorang telah mampu meningkatkan kualitas kesehatan tubuh mereka.

Dalam hal ini peneliti melakukan pengamatan melalui media sosial Instagram dan Twitter untuk melihat akun-akun pengguna media sosial yang aktif dalam menjalankan aktivitas workout. Seperti pada akun instagram @ petitedivaa (gambar $\underline{1)}$, ia merupakan seorang content creator yang cukup terkenal di Instagram dan Youtube yang seringkali membagikan tipstips gaya hidup sehat untuk mendapatkan tubuh yang bugar. Feeds instagramnya pun penuh dengan video-video aktivitas workout dirinya dengan beragam gerakan yang dapat diikuti oleh pengikutnya. Ia juga 
aktif untuk memberikan tips-tips kepada pengikutnya tentang bagaimana cara berolahraga yang benar.

Dalam sebuah postingan pada tanggal 24 September 2020, ia mengatakan bahwa berolahraga merupakan bentuk penghargaan diri dan bentuk mencintai diri sendiri. Selama menjalani gaya hidup sehat dengan memakan makanan sehat dan berolahraga, ia merasakan bahwa gaya hidup sehat yang dijalaninya ini dapat mengubah dirinya menjadi versi yang lebih baik. Alasan@petitedivaa melakukan gaya hidup sehat karena sistem pencernaannya terganggu, bukan karena ingin memiliki tubuh yang ideal. Ia juga menyatakan dulu ia seringkali jatuh sakit dan memiliki kondisi tubuh yang lemah. Dari hal itulah, maka ia memutuskan untuk mengubah pola hidupnya menjadi gaya hidup sehat dan mulai rutin melakukan olahraga. @ petitedivaa saat ini memiliki program yang bernama "PetiteDiva's Virtual Sweat Camp" yang dapat diikuti oleh seluruh kalangan, khususnya wanita.

Pengikut@petitedivaa lainnya adalah @ solmahsh2532 yang juga mengaku sangat menyukai olahraga khususnya workout. Dalam sebuah komentarnya di salah satu postingan di tanggal 23 maret 2021, akun @ petitedivaa, ia mengatakan bahwa alasan ia melakukan workout adalah untuk memperoleh berat badan ideal dan bugar. Ia juga mengatakan bahwa ia ingin mengubah pola hidup yang dijalaninya menjadi pola gaya hidup sehat dengan berolahraga. Menurutnya konten-konten @ petitedivaa sangat bagus karena dapat mengajarkan orang lain bagaimana berolahraga dengan baik agar kesehatan tubuh tetep terjaga.

Berdasarkan data tersebut tampak media sosial sangat memberikan dampak yang besar terhadap gaya hidup para pengakses media sosial tersebut (Agianto et al., 2020), baik yang dinilai positif maupun negatif. Selain itu perilaku yang muncul juga bersifat saling mempengaruhi dan saling mengajak sehingga muncul rangkaian pengikut yang mengikuti apa yang ditayangkan dari masing-masing medianya.

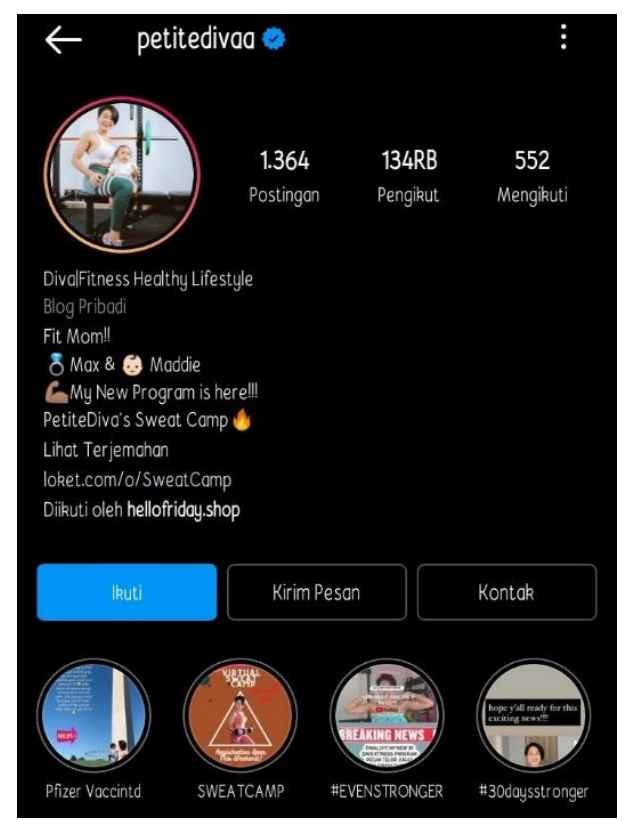

Gambar 1. Instagram menjadi media dalam mempopulerkan perilaku workout

Selain itu, @lannister_agth yang juga merupakan pengikut akun @ petitedivaa, mengaku bahwa ia sudah lama menjadi pengikut akun tersebut dan sudah menjalani beragam program yang dilakukan oleh @ petitedivaa. Ia merasa cocok dengan seluruh program olahraga yang dilakukan oleh akun tersebut. Dengan gerakangerakan workout yang mudah diikuti, maka ia pun dengan mudah dapat mengikuti gerakan-gerakan workout yang dicontohkan oleh@petitedivaa. Ia mengatakan bahwa dengan berolahraga ingin dapat menginvestasi kesehatannya untuk jangka panjang.

Alasan lainnya pun datang dari pengikut akun @ petitedivaa lainnya, pengguna instagram dengan username @inaty_ini mengatakan di laman komentarnya pada tanggal 23 Maret 2021 bahwa ia mengikuti program workout oleh @petitedivaa agar tidak stres memikirkan skripsi. Ia beralasan karena skripsi merasa stres dan mencari pengalihan dengan cara berolahraga. Ia mengatakan bahwa gerakan-gerakan workout yang dicontohkan oleh @ petitedivaa sangat bagus dan mudah diikuti oleh semua orang. 
Akun pengguna instagram lainnya yang seringkali membagikan video-video aktivitas workout adalah @ sallyvarsly (gambar 2). Ia merupakan seorang content creator yang cukup terkenal dan aktif membagikan aktivitas workout melalui media sosial. Jika dilihat dari akun instagramnya, ia seringkali memposting video gerakan workout beserta alat-alat penunjang aktivitasnya saat di rumah. Ia juga banyak melakukan gerakan-gerakan workout yang mudah diikuti saat berada di rumah. Selain memposting gerakan workout, ia juga banyak membagikan makanan-makanan sehat yang dikonsumsinya untuk menunjang gaya hidup sehat yang dijalaninya.

Di Twitter, terdapat base yang sering membahas mengenai berbagai tips kecantikan, seperti skincare, perawatan tubuh, serta workout. Akun Twitter @ohmybeautybank merupakan base twitter yang dapat mengirim menfess dari akun pengirim melalui DM. Biasanya seringkali menfess ini bertanya mengenai rekomendasi gerakan-gerakan workout yang dapat diikuti oleh pemula yang ingin memulai workout. Beberapa pengikut base tersebut akan membalas menfess tersebut dengan akun-akun yang ingin direkomendasikannya. Menfess yang dikirim di base itu juga seringkali berupa tips-tips rekomendasi gerakan workout yang pas untuk mendapatkan tubuh yang ideal. Selain gerakan workout dan rekomendasi akun, biasanya isi menfess tersebut juga mengenai perlunya workout diiringi dengan menjalani gaya hidup yang lain, seperti mengkonsumsi air putih dan makanan yang sehat, serta tips-tips hidup sehat dan cantik lainnya.

Dampak dari kondisi lingkungan yang sedang mengalami masa pandemi COVID19, ajakan untuk berolahraga di rumah pun semakin gencar dipromosikan. Fenomena itu dapat dilihat dari banyaknya postingan di media sosial yang membagikan tips-tips dan contoh-contoh gerakan olahraga yang mudah dilakukan saat di rumah hingga di tempat kerja (Prasetyo, 2014). Workout pun menjadi pilihan utama masyarakat dalam melakukan olahraga di rumah. Dengan menggunakan alat seadanya dan gerakan sederhana mereka turut membantu pemutusan rantai virus COVID-19 dengan berada di rumah, sekaligus dapat meningkatkan imunitas tubuh dan tubuh yang bugar.

\subsection{Standar Kesehatan Pada Workout}

Segala bentuk respon yang dilakukan seseorang terhadap kondisi penyakit atau rasa sakit, sistem pelayanan kesehatan, lingkungan maupun makanan masuk ke dalam kategori perilaku sehat (Adliyani, 2015). Dasar setiap orang melakukan suatu perilaku biasanya dipengaruhi oleh nilai, sikap, dan pengetahuan (Notoadmojo, 2014). Dari dua konsep tersebut maka dapat dinarasikan bahwa perilaku kesehatan merupakan tindakan seseorang untuk menambah kualitas standar sehatnya, walau dalam kondisi tubuh yang sehat. Tindakan ini dapat berupa memelihara, menjaga, mepertahankan, hingga meningkatkan. Ada tiga tujuan yang hendak dicapai seseorang dalam berperilaku sehat, yakni (1) perilaku preventif, yang berarti tindakan manusia yang bertujuan untuk memelihara kesehatannya, hal ini berkaitan dengan tujuan kaum modern melakukan workout yaitu untuk memelihara kesehatan tubuh; (2) perilaku protektif adalah perilaku kesehatan yang bertujuan untuk melindungi tubuh dari gangguan penyakit. Dalam aktivitas workout yang dilakukan saat masa pendemi virus COVID-19 ini pun juga bertujuan agar imunitas tubuh meningkat dan melindungi tubuh dari virus COVID19; (3) perilaku promotif yakni perilaku kesehatan yang dilakukan dengan tujuan untuk meningkatkan kualitas derajat kesehatannya. Hal ini juga berkaitan dengan tujuan melakukan aktivitas workout yaitu untuk mendapatkan tubuh yang bugar. 


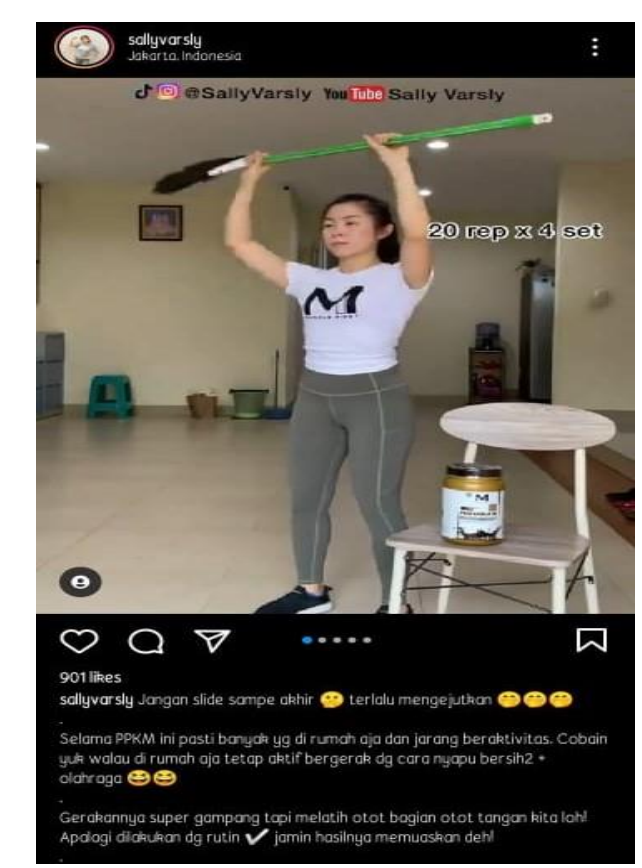

Gambar 2. Populernya workout karena dapat dilakukan di dalam rumah pada masa pandemi

Gaya hidup workout merupakan bentuk aktivitas seseorang, terutama pada kalangan wanita demi meningkatkan dan memelihara kesehatannya. serta mencari cara penyembuhan bila terkena masalah terhadap kesehatan. Begitu pula dengan aktivitas workout yang dilakukan oleh wanita modern yang bertujuan agar dapat meningkatkan derajat kualitas kesehatan, serta memelihara dan menjaga kesehatan tubuh.

Pandangan Becker yang dikembangkan oleh Bloom menunjukkan konsep perilaku sehat merupakan salah satu aspek dalam penentuan derajat kualitas kesehatan masyarakat (Husaini et al., 2017). Melaui pemahaman Becker, maka perilaku kesehatan wanita yang melakukan workout dipengaruhi oleh tiga hal berikut.

Pertama, pengetahuan para wanita yang didapatkan dari beragam sumber informasi berkaitan aktivitas workout, menjadi pengetahuan standar kesehatan mereka. Pengetahuan itu didapatkan melalui melihat dan mendengar perilaku orang lain. Berdasarkan hal ini, kaum modern yang melakukan workout juga memiliki pengetahuan kesehatan bahwa berolahraga pasti dapat menjaga dan meningkatkan kesehatan tubuh.
Kedua, sikap terhadap kesehatan, yakni reaksi atau respon yang ditunjukkan seseorang dalam menyikapi suatu permasalahan kesehatan. Wanita modern yang telah aktif melakukan workout selain mengejar tujuan kesehatan, juga merespon terhadap apa yang mereka senangi maupun tidak. Kesenangan untuk dapat terus menggerakkan badan dan mendapatkan kepuasan dapat beraktivitas dalam keterbatasan waktu dan tempat. Dapat berolahraga dengan memanfaatkan ruangan tinggal yang ada dan tanpa harus memakan waktu yang mengganggu aktivitas lainnya, tetapi bisa memberikan efek yang cepat menjadi dasar gaya hidup ini mudah diminati. Pemilihan gaya hidup ini dipengaruhi terhadap ciri-ciri sikap yang akan diambil (Notoadmojo, 2014), yaitu (1) Thoughts and feeling. Berdasarkan hal ini, aktivitas workout yang dilakukan oleh beberapa informan juga dilalui oleh berbagai pertimbangan salah satunya adalah pertimbangan untuk mendapatkan kualitas kesehatan yang baik. Mereka merasa bahwa dengan melakukan workout dapat meningkatkan kesehatan tubuh dan merasa takut akan terkena obesitas; (2) personal reference. Berdasarkan hal ini, salah satu informan menyatakan bahwa ia melakukan workout karena melihat gaya hidup sehat orang lain. Ia melihat orang lain yang sukses melakukan workout dan mendapatkan tubuh yang ideal. Akhirnya ia pun termotivasi untuk melakukan hal yang sama guna untuk mendapatkan tubuh yang ideal.

Berdasarkan hasil temuan peneliti terhadap akun-akun sosial media penggiat workout seperti@petitedivaa dan @ sallyvarsly memiliki pengikut atau penggemar yang menjadikan mereka sebagai role model atau panutan kesuksesan seseorang dalam menjalankan aktivitas workout. Banyak sekali postinganpostingan media sosial influencer yang aktif membagikan gerakan-gerakan workout di akun mereka sehingga memudahkan seseorang untuk melihat dan menjadikan mereka sebagai acuan dalam melakukan 
aktivitas workout; dan (3) sumber daya (resources), yakni sumber daya yang menjadi pendukung untuk bersikap positif dan negatif terhadap pertimbangan kebutuhan individu. Berdasarkan hal ini, sumberdaya yang mendukung informan untuk melakukan workout adalah smartphone, media sosial, aplikasi-aplikasi kesehatan yang mudah diakses. Di sisi lain hal yang menghambatnya adalah terbatasnya tempat untuk berolahraga bersama teman, terlebih pada kondisi pandemi ketika tempat fasilitas olahraga ditutup sehingga sangat dibutuhkan aktivitas yang aman dilakukan (Wicaksono, 2020).

Melalui smartphone dan media sosial, seseorang dapat mengakses gerakangerakan workout yang mudah diikuti. Seperti pada akun instagram @petitedivaa dan@sallyvarsly yang sering membagikan aktivitasnya. Dengan adanya sumberdaya seperti smartphone, seseorang dapat memiliki pengetahuan tentang kesehatan dan bagaimana caranya menjalankan gaya hidup sehat yang efektif.

Budaya secara sadar mampu mempengaruhi bagaimana seseorang berpikir yang terbentuk pada perilaku yang dilakukan secara berulang-ulang. Dalam kasus yang terjadi di media sosial, seperti Instagram dapat menjadi suatu realitas sosial yang menjadi suatu kebenaran sehingga menentukan norma-norma yang ada (Kertamukti et al., 2018). Hal ini juga terjadi kepada para wanita yang selalu aktif mengupdate informasi standar kesehatan mereka dari media sosial. Berdasarkan data para informan, perlunya kegiatan workout ini dikarenakan anggapan mereka yang merasa memiliki berat badan yang berada di atas rata-rata (overweight). Dengan adanya budaya popular dan media sosial, membuat masyarakat memiliki pandangan mengenai bagaimana seharusnya tubuh ideal seorang perempuan. Seperti yang dialami oleh seorang informan, ia mengatakan bahwa sering diejek atas tubuh yang dimilikinya, perkataan orang lain atas tubuhnya itulah yang membuat ia tidak nyaman, dan akhirnya ia berusaha untuk melakukan aktivitas workout agar tidak mendengar perkataan tidak nyaman orang lain yang ditujukan kepadanya.

Ketiga, tindakan kesehatan, yakni tindakan yang diambil dan kegiatan yang dilakukan seseorang dalam rangka memelihara kesehatannya. Diperlukan fenomena atau kondisi tertentu sebagai faktor pendukung agar perubahan sikap manusia dapat terbentuk dalam tindakan baru. Karena pada aslinya manusia beradaptasi pada perubahan lingkungan yang ditinggali. Melalui pengetahuan kesehatan dan sikap yang diambil akhirnya para informan wanita memutuskan untuk melakukan aktivitas workout yang dapat membuat mereka mendapatkan tubuh yang sehat, ideal dan bugar. Dalam hal ini, pengikut akun media sosial penggiat workout di atas secara sadar mengikuti dan melakukan aktivitas workout. Selain dengan mengikuti kegiatan workout, mereka juga ikut menjalankan tips-tips hidup sehat yang dijalani oleh influencer atau penggiat workout tersebut.

\subsection{Workout Sebagai Bentuk Perubahan Perilaku Kesehatan}

Fenomena gaya hidup workout dapat dikaji melalui teori self efficacy. Teori ini mendefinisikan keyakinan seseorang yang akan melakukan sesuai dengan kemampuannya untuk mencapai suatu titik tertentu yang dipengaruhi oleh pengalamannya di masa lampau (Irwan, 2017). Bila dilihat dengan alasan para pelaku workout. Hal ini bisa jadi terjadi karena keinginan para pelaku workout untuk mendapatkan status sehat yang terbentuk dari postur tubuh dikarenakan pengaruh dari informasi yang didapatkan sebelumnya. Informasi yang secara massif memberikan dampak self efficacy yang efektif.

Para wanita yang mengikuti gaya hidup workout karena pengetahuan awal tentang gaya hidup workout sebelumnya didapatkan dari postingan media Instagram mereka. Sering rutinnya para informan mendapatkan 
informasi terkait postingan workout dengan durasi yang tidak sebentar, maka terjadi proses perubahan terhadap pemahaman kesehatan yang dimunculkan dalam simbolsimbol nyata. Maka, perubahan perilaku mulai dari mengenal di media Instagram dan mempraktikkannya adalah proses perubahan yang terencanakan dan dapat terpengaruhi dari perubahan baik secara internal maupun eksternal. Sejatinya perilaku manusia pasti akan berubah, karena difaktori baik secara internal maupun eksternal.

Perubahan perilaku sebelum seseorang wanita melakukan aktivitas workout dan setelah memutuskan untuk beraktivitas workout adalah dikarenakan oleh meniru orang lain dan penghayatan dari pengalaman pribadi. Seperti yang telah dijelaskan di atas, bahwa pengikut akunakun instagram penggiat workout tersebut mencoba untuk meniru gaya hidup orang yang diikutinya. Mulai dari melakukan aktivitas workout dengan mengikuti gerakan-gerakan workout di postingannya, sampai dengan mengikuti tips-tips menjalani gaya hidup sehat agar tubuh tetap terjaga kesehatannya. Selain dari meniru orang lain, orang yang melakukan workout juga memiliki kesadaran bahwa dirinya perlu berolahraga dari pengalaman pribadinya.

Tidak semua perubahan perilaku karena disebabkan dari pengalaman masa lalu. Terdapat juga temuan yang melihat perubahan perilaku sebagai bentuk dari respon dari stimulus-stimulus. Seperti yang terjadi pada kesadaran perilaku sehat masyarakat di masa pandemi karena tergantung pada respon persepsi masyarakat terhadap penyakit, respon kebijakan pemerintah, mekanisme yang muncul secara otomatis dan praktek adaptasi pada bentuk modifikasi-modifikasi perilaku untuk menjadi sehat (Prastiwi et al., 2020). Selain itu dimungkinkan perubahan perilaku yang didasari dari 3 faktor, yaitu health maintenance, health seeking behavior, dan bentuk perilaku kesehatan lingkungan (Pribadhi, 2011).
Secara garis besar membahas fenomena workout sebagai perubahan perilaku merupakan suatu paradigma yang menyatakan bahwa manusia akan berubah sesuai dengan apa yang mereka pelajari melalui keluarga, teman, maupun diri sendiri (Irwan, 2017). Dari proses pembelajaran itulah yang akhirnya membentuk sebuah perilaku seseorang tersebut. Perubahan perilaku seseorang dapat didasari oleh beberapa pertimbangan berikut.

Complience, karena pemaksaan yang secara tidak langsung dirasakan oleh para pengguna Instagram. Informasi yang massif dengan hastag tertentu, terus secara perlahan dikonsumsi oleh para wanita melalui akun mereka. Informasi tersebut yang diterima tidak dapat diterima sekaligus maupun dikelola dengan baik oleh kesadaran manusia yang mendapatkan informasi. Perilaku workout yang dilakukan meleset dari tujuan utama untuk menjadi sehat, tetapi untuk ikut menjadi trending sehingga berakhir dalam perilaku konsumtif demi mendapatkan simbol-simbol khusus dalam melakukan workout. Seperti pakaian olahraga yang bermerk tertentu hingga alatalat tambahan untuk membantu kegiatan workout. Perubahan karena pemaksaan.

Identification, bentuk meniru perilaku yang dilakukan oleh orang lain. Sebagai seorang manusia, meniru tindakan yang dilakukan oleh orang lain bersifat alami dan bahkan bentuk proses pembelajaran dalam kehidupan. Postingan maupun video yang menampilkan gerakan-gerakan workout mampu menarik rasa ketertarikan dari para pengguna media sosial. Dari modal rasa ketertarikan, berkembang kesadaran untuk ikut melakukan kegiatan workout secara mendalam sehingga pengetahuan, idealisme, fungsi hingga manfaat dari kegiatan workout dapat tersalurkan kepada calon-calon pelaku gaya hidup tersebut. Berawal dari ketertarikan kemudian meniru dan berakhir belajar sehingga menambah pemahaman konsep perilaku kesehatan yang dibawa dari kegiatan workout tersebut. Perubahan karena meniru. 
Internalization merupakan tahapan perubahan perilaku yang disadari akan kebutuhan pelakunya untuk berubah. Para wanita yang melakukan workout tidak seluruhnya hanya sebatas meniru. Tetapi ada yang benar menyadari manfaat dibalik gerak-gerak badan yang dilakukan saat workout dilakukan. Walaupun sumber awal masih karena meniru dan mengadopsi dari postingan akun yang menunjukkan gerakan-gerakan workout, tetapi terdapat yang merasakan gerakan tersebut diperlukan dan dirasakan sangat membantu mereka selama melewati masa pandemi. Mereka harus mengurangi kegiatan di luar rumah, tetapi tertuntut untuk melakukan gerakan-gerakan yang cukup agar respon kesehatan badan dapat memberikan pertahanan dari penyebaran virus. Perubahan karena kebutuhan.

\section{Kesimpulan}

Kemajuan teknologi di zaman modern saat ini berpengaruh pada pola perilaku atau gaya hidup sehat masyarakat modern. Perilaku sehat yang saat ini sedang digandrungi untuk meningkatkan kesehatan tubuh adalah workout. Melalui media sosial, workout saat ini telah menjadi sebuah trend yang meluas pada masyarakat modern dan menjadi sebuah gaya hidup sehat baru.

Workout muncul tidak hanya sebagai bentuk gaya hidup yang modern, tetapi sebagai pilihan aktivitas yang berfungsi dalam meningkatkan kualitas kesehatan para pelaku, terutama wanita. Ditambah perubahan konsep sehat maupun sakit dalam wanita modern, menjadikan workout sebagai aktivitas yang dibutuhkan apalagi di masa pandemi Covid-19.

Kemunculan gaya hidup workout yang ter-posting secara aktif di media sosial, menunjukkan fungsi media sosial tidak lagi sebagai media informasi. Media sosial dapat memberikan kontribusi kesehatan secara tidak langsung. Postingan workout terkonsumsi oleh para wanita modern yang aktif menggunakan media sosial sehingga memberikan dorongan untuk ikut melakukannya dalam kehidupan mereka, dan menjadi aktivitas baru dengan tujuan mendapatkan standar kesehatan yang dikehendaki.

Dorongan tersebut bila dilihat dari teori self efficacy merupakan bentuk perilaku meniru yang dilakukan berulangulang dan menjadi bentuk kesadaran baru. Proses peniruan tersebut dengan mempertimbangkan aspek compliance, identification dan internalization. Workout adalah hasil produk budaya modern yang terbentuk dari perjalanan perubahan kesadaran kesehatan sebagai bentuk adaptasi manusia dengan perubahan lingkungan.

Kesehatan akan selalu menjadi bahan pencaharian manusia secara alamiah. Dengan perubahan lingkungan, maka sumber untuk mendapatkan standar kesehatan juga ikut berkembang. Tidak hanya dari faktor makanan, obat maupun kegiatan olahraga, tetapi media sosial juga memiliki peran dalam mempengaruhi standar kesehatan yang baru sehingga diharapkan kita dapat benar-benar menyadari potensi yang mampu membantu kehidupan kita untuk hidup lebih sehat di masa lingkungan alam yang semakin sakit.

\section{Daftar Pustaka}

Achmad, Z. A., \& Ida, R. (2018). Etnografi Virtual Sebagai Teknik Pengumpulan Data Dan Metode Penelitian. The Journal of Society \& Media, 2(2), 130-145.

https://doi.org/10.26740/jsm.v2n2.p1 30-145

Adliyani, Z. O. N. (2015). Pengaruh Perilaku Individu terhadap Hidup Sehat. Majority, 4(7), 109-114. https://doi.org/10.22146/jpsi.10037

Afrizal. (2017). Metode Penelitian Kualitatif: Sebuah Upaya Mendukung Penggunaan Penelitian Kualitatif dalam Berbagai Disiplin Ilmu. Rajagrafindo Persada

Agianto, R., Setiawiti, A., \& Firmansyah, 
R. (2020). Pengaruh Media Sosial Instagram Terhadap Gaya Hidup dan Etika Remaja. TEMATIK - Jurnal Teknologi Informasi Dan Komunikasi, 7(2 SE-Articles), 130139.

https://jurnal.plb.ac.id/index.php/tem atik/article/view/461

Bungin, B. (2017). Penelitian Kualitatif: Komunikasi, Ekonomi, Kebijakan Publik, dan Ilmu Sosial Lainnya. Kencana Prenada Media Group

Choirudin, M. (2015). Penyesuaian Diri: Sebagai Upaya Mencapai Kesejahteraan Jiwa. Hisbah: Jurnal Bimbingan Konseling Dan Dakwah Islam, 12(1), 1-20. https://doi.org/10.14421/hisbah.2015. 121-07

Doloy, F., Tasik, F. C. M., \& Mokalu, B. J. (2020). Kajian Gaya Hidup Hedonisme Masyarakat Desa Tateli Tiga Kecamatan Mandolang Kabupaten Minahasa. Jurnal Holistik, 13(3), 1-15. https://ejournal.unsrat.ac.id/index.ph p/holistik/article/view/29603

Hermawati, Y., Priyatna, A., \& Adji, M. (2016). Instagram dan Mitos Kecantikan Perempuan Muslim. Riksa Bahasa: Jurnal Bahasa, Sastra, Dan Pembelajarannya, 2(2), 199215.

http://journals.sagepub.com/doi/10.1 177/0163443712468605

Hine, C. (2000). Virtual Ethnography. Sage Publications

Husaini, Rahman, F., Marlinae, L., Rahayu, A., Praedevy, K., Rosadi, D., Laily, N., \& Wulandari, A. (2017). Buku ajar antropologi sosial kesehatan. Zukzez Express

Irwan. (2017). Etika dan Perilaku Kesehatan. Absolute Media

Kertamukti, R., Nugroho, H., \& Wahyono,
S. B. (2018). Komunikasi Visual: Fantasi Tubuh Wanita Kelas Menengah di Instagram. Jurnal Kajian Komunikasi, 6(2), 231-246. https://doi.org/10.24198/jkk.v6i2.179 25

Khairunnisa, Sabrian, F. \& Safri. (2015). Hubungan Gaya Hidup Dengan Prestasi Akademik Makasiswa Keperawatan Universitas Riau. JOM, 2(2), 1186-1194.

https://jom.unri.ac.id/index.php/JOM PSIK/article/view/8283

Lodeng, A. (2018). Pengaruh Gaya Hidup Hedonis Terhadap Perilaku Konsumtif Menurut Ekonomi Islam. Skripsi UIN Islam Negeri Raden Intan Lampung, 24-28. http://repository.radenintan.ac.id/374 6/

Loischofeer, A. J., \& Darmawan, D. R. (2021). Tradisi Tolak Bala Sebagai Adaptasi Masyarakat Dayak Desa Umin Dalam Menghadapi Pandemi Di Kabupaten Sintang. Habitus: Jurnal Pendidikan Sosiologi Dan Antropologi, 5(1), 53-68. https://jurnal.uns.ac.id/habitus/article /view/53723/32461

Martha, D., Wardah, M., Ananda, M., Ulya, R., \& Sari, V. R. (2020). Fenomena Gaya Hidup Masyarakat Dalam Era Belanja Daring. Sains Sosial Dan Humaniora, 4, 55-62. https://doi.org/10.30595/jssh.v4i1.44 15

Misbahuddin, M., \& Sholihah, A. M. (2018). Pakaian sebagai Penanda: Konstruksi Identitas Budaya dan Gaya Hidup Masyarakat Jawa (20002016). El-Wasathiya: Jurnal Studi Agama, 6(2), 113-133. https://doi.org/https://doi.org/10.5281 /zenodo.3522966

Notoadmojo, S. (2014). Ilmu Perilaku Kesehatan. Rineka Cipta 
Prasetyo, Y. (2014). Olahraga Bagi Orang yang Sibuk Di Kantor. Jurnal Ilmiah WUNY, 16(4), 1-10. https://doi.org/10.21831/jwuny.v16i4 .3516

Prastiwi, A., Darmawan, D. R., \& Efriani, E. (2020). Perilaku Kesehatan Pada Masa Pandemi Covid-19. Culture \& Society: Journal Of Anthropological Research, 2(2), 65-75. https://doi.org/10.24036/csjar.v2i2.59

Pribadhi, P. A. (2011). Resiprositas Dalam Kehidupan Sosial Ekonomi Masyarakat (Studi Kasus Pada Masyarakat Kelurahan Kauman Kabupaten Blora). Skripsi Universitas Negeri Semarang, 29-34. http://lib.unnes.ac.id/8138/1/8496.pdf

Prihatiningsih, W. (2017). Motif Penggunaan Media Sosial Instagram Di Kalangan Remaja. Communication, 8(1), 51-65. https://doi.org/10.36080/comm.v8i1. 651

Primanita, A. (2011). Hubungan Antara Persepsi Tentang Sakit Dengan Pemanfaatan Pelayanan Kesehatan Oleh Peserta Jaminan Kesehatan Masyarakat Di Puskesmas Gunungpati Kota Semarang. Skripsi Universitas Negeri Semarang, 9-21. http://lib.unnes.ac.id/5819/1/7564.pdf

Rohman, Y. F. (2020). Transformasi Gym: Antara Olahraga, Simbol, dan Representasi Status Sosial. Jurnal Socius: Journal of Sociology Research and Education, 7(1), 1-12. https://doi.org/10.24036/scs.v7i1.172

Safuwan, M. P. (2007). Gaya Hidup, Konsumerisme dan Modernitas. Jurnal SUWA Universitas Malikussaleh, V(1), 38-46. http://repository.unimal.ac.id/id/eprin $\mathrm{t} / 1342$

Suharjana. (2019). Kebiasaan Berperilaku Hidup Sehat dan Nilai-nilai
Pendidikan Karakter. Jurnal Pendidikan Karakter, 11(2), 189201.

https://journal.uny.ac.id/index.php/jp ka/article/view/1303/1084

Susanti, E., \& Kholisoh, N. (2018). Konstruksi Makna Kualitas Hidup Sehat (Studi Fenomenologi pada Anggota Komunitas Herbalife Klub Sehat Ersanddi Jakarta). LUGAS Jurnal Komunikasi, 2(1), 1-12. https://doi.org/10.31334/jl.v2i1.117

Tewal, A. Y., Mewengkang, N. N., \& Londa, J. . (2018). Pengaruh Media sosial Terhadap Gaya Hidup Remaja di Desa Raanan Baru Kecamatan Motoling Barat Kabupaten Minahasa Selatan. Jurnal Acta Diurna, 7(4), 110.

https://ejournal.unsrat.ac.id/index.ph p/actadiurnakomunikasi/article/view/ 20994

Triyono, S., D., K. \& Herdiyanto, Y., K. (2018). Konsep Sehat Dan Sakit Pada Individu Dengan Urolithiasis (Kencing Batu) Di Kabupaten Klungkung, Bali. Jurnal Psikologi Udayana, 4(02), 263-276. https://doi.org/10.24843/jpu.2017.v0 4.i02.p04

Utomo, A. W. (2020). Upaya bersepeda sebagai moda transportasi serta gaya hidup baru menjaga kebugaran jasmani. Seminar Nasional Fakultas Ilmu Kesehatan Dan Sains, 1(1), 118126.

http://prosiding.unipma.ac.id/index.p hp/SENFIKS/article/view/1688

Wicaksono, A. (2020). Aktivitas Fisik Yang Aman Pada Masa Pandemi Covid-19. Jurnal Ilmu Keolahragaan Undiksha, 8(1), 10-15. https://doi.org/10.23887/jiku.v8i1.28 446

Winastya, K. P. (2020). Workout Adalah Aktivitas yang Dilakukan untuk Memelihara Kebugaran, Ketahui 
Jenisnya. Merdeka.Com.

https://www.merdeka.com/trending/

workout-adalah-aktivitas-yang-

dilakukan-untuk-memelihara-

kebugaran-ketahui-jenisnya-

kln.html?page $=7$

Zed, M. (2014). Metode penelitian

kepustakaan. Yayasan Obor

Indonesia 